\title{
Knowledge Management in Rumah Tunggu Kelahiran (RTK) in Health Services in Sinjai District
}

\author{
$1^{\text {st }}$ Mochamat Nurdin \\ Department of Government Sciences \\ High School of Social and Political \\ Science Department of Sinjai Regency \\ Sinjai Regency South Sulawesi \\ Province, Indonesia \\ moch.nurdin21@gmail.com \\ $4^{\text {th }}$ Umar Congge \\ Department of Public Administration \\ High School of Social and Political \\ Science Department of Sinjai Regency \\ Sinjai Regency South Sulawesi \\ Province, Indonesia \\ umarcongge67@gmail.com
}

\author{
$2^{\text {nd }}$ A. Jamaluddin \\ Department of Public Administration \\ High School of Social and Political \\ Science Department of Sinjai Regency \\ Sinjai Regency South Sulawesi \\ Province, Indonesia \\ a.jamaluddin60@gamail.com
}

\author{
$3^{\text {rd }}$ Asriadi AR Department of \\ Government Sciences \\ High School of Social and Political \\ Science Department of Sinjai Regency \\ Sinjai Regency South Sulawesi \\ Province, Indonesia \\ asriadi08@gmail.com
}

\begin{abstract}
Knowledge management has an effect on organizational performance and becomes an interesting issue to be studied in public sector organizations. Sinjai District Rumah Tunggu Kelahiran (RTK) has received two awards TOP 99 and TOP 40 Public Service Innovations at the Real Work Week of the Indonesian Mental Revolution held in Solo- Surakarta City at the end of August 2017. Based on this, a research on the management of RTK was conducted in health services. This research was conducted at RTK in Sinjai Regency, South Sulawesi Province, Indonesia in MarchMay 2019. The research method used was a qualitative method, with a type of phenomenology. The data collected are primary data and secondary data, with methods using observation techniques, document review, and interviews. Determination of informants is determined purposively. Furthermore, analyzing the data by data reduction, data presentation and drawing conclusions/verification. The results showed that of the four dimensions namely; (a) building knowledge (knowledge building), knowledge management is done by learning from personal experience, non-formal training sourced from books, and peers as well as the person in charge of the Waiting for Birth (RTK). (b) have knowledge (holding knowledge), knowledge management refers to what is known from the school, lectures and parental advice. (c) pool of knowledge (knowledge pool) Knowledge management refers to knowledge management systems sourced from the internet and friendships conducted by exchanging ideas, and (d) the use of knowledge (use of knowledge), knowledge management that is known to be applied simply and influenced by serving culture such as sipakatau, sipakainge and sipakelebbi.
\end{abstract}

Keywords - knowledge management, Rumah Tunggu Kelahiran, health services

\section{INTRODUCTION}

Health development is part of the Indonesian government's efforts related to national development to increase understanding and awareness as well as the willingness and ability to live healthy for everyone in order to realize an improved degree of public health. Health development is a fundamental part of efforts to improve the quality of healthy human resources so as to realize the acceleration of the achievement of national development goals.

Based on the Indonesian Demographic and Health Survey (SKDI) in 2012, it was found that the maternal mortality rate was 359 per 100,000 live births. This mortality rate has decreased when compared to data from the Indonesian Demographic and Health Survey (SKDI) in 1991 which was 390 per 100,000 live births, although the decline was only 36 or an average of $2 \%$ per year. While the global target of the 5th MDGs (Millennium Development Goals) is to reduce maternal mortality (MMR) to 102 per 100,000 live births in 2015 .

The expected global target was apparently not achievable. One of the evidences is the data presented is from the ASEAN Millennium Development Goals (MDGs) in 2017. The data shows that in 2015 maternal mortality in Indonesia still reached 305 per 100,000. This figure is three times higher than the MDGs target of Indonesia, which is 102 per 100,000. Even with this figure, Indonesia ranks the country with the second highest mortality rate in Southeast Asia after Laos, with a mortality rate of 357 per 100,000 live births [1].

One effort to reduce maternal mortality is that every delivery should be assisted by competent health workers in health care facilities. Therefore, every pregnant woman must obtain easy access to health services. But in reality, many pregnant women are unable to access health services, partly because of geographical constraints, lack 
of health workers, a culture that is not supportive, or has no funds [2].

The research location is unique because the Rumah Tunggu Kelahiran (RTK) is a delivery waiting house for patients who live in the Nine Islands or islands where the distance from the district capital is 1 hour by using a speedboat or a motor boat with an outboard engine. To visit the Nine Islands and each island can only be crossed by sea and the distance of each village is very far apart. a community health vehicle that has been awarded the Top 99 Public Service Innovation and Top 40 in health services. Therefore, it is interesting to know the knowledge management of health workers at Rumah Tunggu Kelahiran (RTK) in providing services.

Based on the phenomena found, the focus of observation in this study is how knowledge management at Rumah Tunggu Kelahiran (RTK) in providing services. This is done because it realizes the importance of the strength of human resources with optimal performance so it is easy to adjust to change.

\section{METHODOLOGY}

This research was conducted at Rumah Tunggu Kelahiran in Sinjai Regency, South Sulawesi Province, Indonesia in March to May 2019. The research method used was a qualitative method, with the type of phenomenological research that is by paying attention and examining the focus of the phenomenon to be studied, which looked at various subjective aspects from the behavior of the object of research (expressing symptoms or phenomena thoroughly and contextually)

Data collected in the form of primary data are the results of interviews to answer research problems and to supplement data obtained from these sources of information, then need to be supported by secondary data. Secondary data obtained are supporting data and information in this study in the form of documents that provide confirmation or sharpen the conclusions of the focus of the study. Furthermore, researchers conduct data mining by conducting in-depth interviews with objects or informants in the study, as well as making direct observations about how object of research.
After that, analyzing the data is done by basing on the assumptions of the answers to the research questions that have been made, through the stages in the form of research objectives to be achieved. In this case the process of data analysis activities includes a) the stage of data collection, b) reducing data to get the main themes that are considered to have relevance to the research problem, c) data assessment, which is carried out by categorizing primary data and secondary data with the recording system relevant, d) interpret the data, which is done by critically analyzing the data collected and finally comes to a conclusion. The next step is to formulate the results of the study so that the data obtained can be a conclusion, as an answer to the research question. This is in accordance [3], that in qualitative research data processing and analysis are inseparable activities. This can be seen in the stages of qualitative data analysis, namely data reduction, data presentation and drawing conclusions /verification.

\section{RESULTS AND DISCUSSION}

\section{A. Brief Overview of Sinjai Regency Rumah Tunggu Kelahiran}

Waiting house is a place or room that is near a health facility (hospital, health center, Poskesdes) that can be used as a temporary shelter for pregnant women and their companions (husband / cadre / shaman or family) for several days, while waiting for delivery to arrive and some days after delivery [4].

Sinjai District Rumah Tunggu Kelahiran (RTK) aims to bring access to health services for pregnant, childbirth, childbirth, and newborn babies so that the number of deliveries in health services increases and decreases complications in pregnant, childbirth and childbirth women and newborns especially residents of Pulau Sembilan [5].

This is in line with the statement of [6], that in order to increase the productivity of RTK public service innovation requires the role of individuals, organizational structure, and culture. Rumah Tunggu Kelahiran (RTK) of Sinjai Regency can be seen in the table of the number of patients waiting for birth in table 1 as follows:

TABLE 1. NUMBER OF PATIENTS RUMAH TUNGGU KELAHIRAN (RTK) IN 2012-2017

\begin{tabular}{|c|c|c|c|c|c|c|c|c|c|}
\hline \multirow[t]{2}{*}{ Year } & \multirow{2}{*}{$\begin{array}{c}\text { Amount } \\
\text { Bumil }\end{array}$} & \multirow{2}{*}{$\begin{array}{l}\text { Amount } \\
\text { Bulin }\end{array}$} & \multirow{2}{*}{$\begin{array}{l}\text { Maternity on } \\
\text { The Island IX }\end{array}$} & \multicolumn{2}{|c|}{ Bumil Risk Asked } & \multicolumn{2}{|c|}{ Post-Wife Mother } & \multicolumn{2}{|c|}{ Newborn Baby } \\
\hline & & & & $\begin{array}{l}\text { Directly to } \\
\text { RS }\end{array}$ & $\begin{array}{c}\text { Through } \\
\text { RTK }\end{array}$ & $\begin{array}{l}\text { Directly to } \\
\text { RS }\end{array}$ & $\begin{array}{l}\text { Through } \\
\text { RTK }\end{array}$ & Go Home & $\begin{array}{c}\text { Throug } \\
\text { h } \\
\text { prk } \\
\end{array}$ \\
\hline 2014 & 163 & 127 & 111 & 12 & 2 & 14 & 2 & 14 & 2 \\
\hline 2015 & 162 & 129 & 112 & 6 & 11 & 14 & 3 & 14 & 4 \\
\hline 2016 & 105 & 61 & 39 & 5 & 20 & 22 & $\mathbf{0}$ & 22 & 0 \\
\hline 2017 & 142 & 136 & 34 & 5 & 8 & $\mathbf{0}$ & $\mathbf{0}$ & $\mathbf{0}$ & $\mathbf{0}$ \\
\hline AMOUN & 572 & 453 & 296 & 28 & 41 & 50 & 5 & 50 & 6 \\
\hline
\end{tabular}

Source: Primary Data, RTK of Sinjai Regency (2019).

Based on the data in Table 1 shows that the number of patients served by the Maritime Rumah Tunggu Kelahiran consists of three types of patients namely; (a) maternal health services, (b) maternity services, and (c) newborn services. For health services for pregnant women, health workers are divided into groups (at most four groups) and each group consists of 2 officers who have the ability and 
expertise in providing care to pregnant women before giving birth. For each patient the service is given for 1 month or according to the patient's needs and is generally free of charge. Then for the service of mothers giving birth and baby care is done intensively from the preparation of childbirth to childbirth. Likewise, infant care is carried out by appointed officers according to a predetermined schedule. This care service for pregnant women and infants is carried out for a maximum of 1 month and there are even officers who visit the homes of newly born housewives if the mothers have just given birth and do not wish to be hospitalized. Thus, Rumah Tunggu Kelahiran in Sinjai District as a place of health care must apply the concept of knowledge management. Knowledge management will have a positive influence on health services for pregnant women, childbirth, postpartum, and newborn babies.

In this study, knowledge management is used in an organizational perspective, Wiig Knowledge Management (KM) which is used to develop the quality of knowledge in achieving high performance which includes:

1. Build Knowledge (BK)

2. Hold Knowledge (HK)

3. Pool (Gathering) Knowledge (PK)

4. Use Knowledge (UK)

Based on the strength of the contract, the Wiig Knowledge Management (KM) approach can be involved into creation, source, compilation, transformation, dissemination, application and realization of values [7].

Knowledge management is not only useful for public service organizations but also companies. This is in line with [8], that some of the benefits of knowledge management for companies include: (1) Time and cost savings; with a well-structured source of knowledge, it will be easy for companies to use this knowledge for other contexts, so the company will be able to save time and costs. (2) Increase in knowledge assets; The source of knowledge will provide convenience for each employee to utilize it, so that the process of utilizing knowledge in the company environment will improve, which in turn will drive the creativity and innovation process more broadly and each employee can increase his competence. (3) Adaptability; The company will be able to easily adapt to changes in the business environment that occur. (4) Increasing productivity; Existing knowledge can be reused for processes or products to be developed, so that the productivity of the company will increase.

\section{B. Knowledge Management of RTK Officers in Providing Services}

Knowledge management can be defined as an activity to plan, collect and organize, lead and control data and information that is owned by a company which is then combined with various thoughts and analyzes from various competent sources [9].

Knowledge Management is a systematic process for finding, selecting, organizing, abstracting and presenting knowledge in certain ways, so that workers are able to utilize and improve knowledge acquisition in a specific field of study, for later there is an institutionalization process so that the knowledge created becomes company knowledge [10].

Identified the main purpose of knowledge management as an effort "to make a company act intellectually by facilitating its creation by channeling quality knowledge". Wiig's knowledge management cycle explains how knowledge is built and used by individuals or organizations. There are four stages in this cycle, namely: (1) Build Knowledge, (2) Hold Knowledge, (3) Pool (Collect) Knowledge, (4) Use Knowledge [11].

\section{Building Knowledge (building knowledge)}

Knowledge is the result of human sensing, or the result of knowing someone about objects through their senses (eyes, nose, ears, and so on). Most of one's knowledge is obtained through the sense of hearing, and sense of sight [12]. The basic assumption of learning is how to interpret as an active process in building knowledge or constructing meaning. The process of building meaning is carried out continuously (throughout life). The meaning of learning is based on a constructivist view. Contructivism is a view of how a person learns, which explains how humans build their understanding and knowledge of the world around them through the recognition of the surrounding objects that are reflected through their experiences. When we discover something new, we reconstruct it. With our initial ideas and experiences, so the possibility of that knowledge changes our beliefs or is new information that is ignored because it is something that is not relevant to the initial idea [13].

Knowledge factors that are considered as supporting organizational goals are expected to be able to provide positive change for the company, because the implementation of duties and obligations is in accordance with the responsibilities of employees in their respective fields [14]. Furthermore, building knowledge leads to activities ranging from market share research, surveys, competitor knowledge, and data mining applications. Building knowledge rests on five activities: (1) gaining knowledge, (2) knowledge analysis, (3) rebuilding / combining knowledge, (4) organizing knowledge based on systems, (5) organizing knowledge [11].

Rumah Tunggu Kelahiran (RTK) in Sinjai District in the application of knowledge management in the building knowledge dimension has been carried out with efforts to learn from personal experience, non-formal training sourced from books, and peers and the person in charge of Rumah Tunggu Kelahiran (RTK). This is in line with [15], in general the implementation of public services in the form of RTK innovations has valid and accurate sources of information so that the implementation of health services is fast and does not require a long waiting time.

\section{Having Knowledge (holding knowledge)}

Holding knowledge consists of remembering, gathering knowledge in a repository, embedding knowledge in a repository, and archiving knowledge. Since knowledge means that an individual has stored an object of 
knowledge (ie knowledge that has been internalized or understood by a particular individual), gathering knowledge in a repository means that knowledge has been stored computerized which allows it to be used by organizational memory. Implanting knowledge consists of ensuring that it is part of business procedures (for example, added to manual procedures or training courses) [11].

Factors influencing a person's level of knowledge include: (1) Education; the higher the level of one's education, the easier it is to receive information so the more knowledge he has. Conversely, a lack of education will hinder the development of one's attitude towards new values that are introduced. Something that someone has experienced will increase knowledge about something that is non formal. (2) Sources of information; people who have many sources of information will have more knowledge. (3) Environment; in the environment a person will gain experience which will affect the way of thinking, where a person will learn good things and also bad things depending on the nature of the group. (4) Social Economy; low socioeconomic level causes limited costs for education, so that knowledge is also low. (5) Age; increasing a person's age can affect the increase in knowledge gained, but at certain ages (old age) the ability to accept or remember something knowledge will decrease [12].

Rumah Tunggu Kelahiran (RTK) in Sinjai Regency in the application of knowledge management in the holding knowledge dimension refers to what is known from schools, lectures and parental advice. This is in line with [12], the scope of education consists of informal, non-formal and formal education. Informal education is education that is obtained by someone at home in a family environment. Non-formal education includes a variety of special businesses organized in an organized manner. While formal education is education that has a particular form or organization such as those found in schools or universities. Next [15], the individual's interest or need to innovate in the workplace is determined by the support received from the organizational environment where the individual is.

\section{Collection of Knowledge (pool knowledge)}

Knowledge is collected with the aim of answering the problems of daily life faced by humans. The systematic features of science show that science is a variety of information and data that are arranged as a collection of knowledge that has an ordered interdependence (orderly relationship) [16]. Furthermore [17], personal knowledge is the knowledge acquired by employees in the form of experience, both from daily events or from other sources.

There are three processes that are carried out in the implementation of knowledge management to be ableto improve employee performance. The process is knowledge creation, knowledge sharing, and implementation. Knowledge creation is the formation of knowledge in the company. Knowledge sharing is sharing knowledge already owned by employees to avoid knowledge loss. And the last implementation is how to apply the knowledge that has been obtained by employees that can simplify the duties and responsibilities [14].

Rumah Tunggu Kelahiran (RTK) in Sinjai Regency in the application of knowledge management in the pool of knowledge (pool knowledge) dimensions refers to the knowledge management system sourced from the internet and friendships conducted by exchanging ideas. This is in line with the statement of [18], one way of knowledge conversion is socialization. This socialization is used to emphasize the importance of joint activities between knowledge sources and knowledge recipients in the process of tacit knowledge conversion. Because tacit knowledge is highly influenced by the context and is very difficult to be formalized, to transmit tacit knowledge from one individual to another requires experience that is formed through joint activities, such as being together in one place, spending time together, or living in the same environment. To achieve good performance levels, efforts are made to improve employee performance by applying knowledge management to the daily work culture in the form of knowledge sharing, which is routinely held every week at each unit. This is very effective because it can reduce the miss communication in doing work. It is also done by utilizing technology through social media so that employees also often use it to exchange information about work [14]. Furthermore [15], the information provided can be in the form of information, statements, ideas, and signs that contain values, meanings and messages, both data, facts and explanations that can be seen and heard in various packaging and format in accordance with the development of electronic and non- electronic information and communication technology.

\section{Use of Knowledge (use knowledge)}

Knowledge management can be used for individual employees, communities of practice, and their own organizations [11]. Each provides benefits, namely: (1) For individuals; help individuals in their work and save time for better decision making and problem solving, build community ties in organizations, help keep individuals up to date, provide challenges and opportunities to contribute. (2) For the practice community; develop professional skills, provide teaching and learning processes, better facilities in the network and collaborate to develop a code of ethics that can be obeyed by members, develop common language. (3) As for the organization; help execute strategies, solve problems quickly, carry out best practices, increase knowledge in products and services, gather ideas and increase opportunities for innovation, enable organizations to advance in competition, build organizational memories.

Rumah Tunggu Kelahiran (RTK) in Sinjai Regency in the application of knowledge management in the use of knowledge dimension is applied simply and influenced by serving culture such as sipakatau, sipakainge and sipakelebbi. For the use of the knowledge they have, the health workers in RTK help one another and provide information for what they know themselves, they support each other in carrying out their work. This is in line with [19], personal knowledge is unique because no one has the exact same knowledge. Individual knowledge is formed by formal and non-formal education that he gets. For example: life experiences, habits or cultural heritage formed from his family, or the influence of the environment in which he 
lives. With the knowledge possessed by individuals, and that knowledge is stored properly in writing and in computer folders, then when needed this knowledge will be easily accessed. This supports someone to be more creative. However, if the knowledge is not able to be remembered or cannot be accessed, then the person will repeat things that have already existed or in this case go backwards to gather the required knowledge. Furthermore [15], the implementation of RTK health services in which health workers as the spearhead of public services have a high enough individual motivation, especially in providing health services to pregnant and breastfeeding women from the poor.

\section{CONCLUSIONS}

Based on the results of the study, it can be concluded that the knowledge management of Rumah Tunggu Kelahiran (RTK) officers in providing health services in Sinjai Regency includes four dimensions namely; (a) building knowledge (knowledge building), knowledge management is done by learning from personal experience, non-formal training sourced from books, and peers as well as the person in charge of Rumah Tunggu Kelahiran (RTK). (b) Have knowledge (holding knowledge), knowledge management refers to what is known from the school, lectures and parental advice. (c) Pool of knowledge (knowledge pool) Knowledge management refers to knowledge management systems sourced from the internet and friendships conducted by exchanging ideas, and (d) the use of knowledge (use of knowledge), knowledge management that is known to be applied simply and influenced by serving culture such as sipakatau, sipakainge and sipakelebbi.

\section{REFERENCES}

[1] Kumparan Sains. Angka Kematian Ibu dan Bayi Indonesia Tertinggi Kedua di Asia Tenggara.https://kumparan.com/kumparansains/angka- kematianibu-dan-bayi-indonesia-tertinggi kedua-di-asia-tenggara. (diakses tanggal 25 Nopember 2019), 2018

[2] Joint Committee on Reducing Maternaland Neonatal Mortality and Neonatal Mortality in Indonesia: Saving Lives, Saving The Future. The National Academies Press. 1-131 p, 2013.

[3] Saldana AM., Johnny, Miles, Mattehew B, Huberman. Oualitative Data Analysis: A Methods Sourcebook. London: Sage Publications, 1994

[4] Kemenkes RI. Profil Kesehatan Indonesia Tahun 2014. Kementerian Kesehatan RI, Jakarta, 2015.

[5] Asriadi AR. Inovasi Implementasi Pelayanan Kesehatan Rumah Tunggu Kelahiran (RTK) Kabupaten Sinjai. Disertasi Program Studi Administrasi Publik Pascasarjana Universitas Hasanuddin, Makassar. Hal 13, 2019.

[6] Steelman, T. A. Implementing Innovation Fostering Enduring Change In nvironmental and Natural Resource Governance, Georgetown University Press/Washington, DC, 2010.

[7] D. Kimiz, Knowledge Management in Theory and Practice, 2nd ed. Cambridge, Massachusetts London: The MIT Press, 2011.

[8] Davenport, T. and Prusak, L. 1997. Working Knowledge, Harvard 1998, ISBN 0-87584-655-6, 1998.

[9] Maimunah, El Rayeb, S. Augury, Siti. Knowledge management sebagai Salah Satu Jembatan Pengembangan Institusi Unggulan.
Jurnal AMIK Raharja, Vol. 2, No. 1, 2008: 80 - 90. Tangerang: AMIK Raharja, 2008.

[10] Tjakraatmadja, J.H. Donald, C.L. Knowledge Management: dalam konteks organisasi pembejarar. Sekolah Bisnis dan Manajemen (SBM), Institut Teknologi Bandung, Bandung, 2006.

[11] Dalkir, K. Knowledge Management in Theory and Practice. Cambridge, MA: MIT Press, 2011.

[12] Notoatmodjo, S. Metodologi Penelitian Kesehatan. Rineka Cipta, Jakarta, 2010.

[13] PPG. Pembelajaran Aktif, Kreatif, Efektif, dan Menyenangkan (PAKEM). http://staffnew.uny.ac.id/upload/132303693/pengabdian/bahan+aj ar++PPG+PAKEM.(diakses tanggal 25 Nopember 2019), 2019.

[14] Sa'adah, M.N., Hari, S. Analisis Penerapan Knowledge Management pad PT. Telkom Indonesia (Persero) Divre IV Semarang.Jurnal Ilmu Administrasi Bisnis Volume 6, Nomor 3, Tahun 2017.Jurusan Ilmu Administrasi Bisnis Fakultas Ilmu Sosial dan Ilmu Politik Universitas Diponegoro, Semarang, 2017.

[15] Asriadi, AR., et al. The Innovation In Implementing Health Services For Rumah Tunggu Kelahiran (RTK) In Sinjai Regency. International Journal of Academic Research and Reflection. Vol. 7 No. 3, 2019. ISSN 2309-0405 hal 39, 2019.

[16] Zaini, M. Pengetahuan dan Manusia (Hakikat dan Tujuan).IAIN Madura.https://www.researchgate.net/publication/329371546 (diakses tanggal 26 Nopember 2019), 2018.

[17] Carrillo, P., Robinson, H., Al-Ghassani, A., Anumba, C. Knowledge management in UK Construction: Strategies, Resources and Barriers. Project Management Journal, 35, (1), p. 46, 2004.

[18] Munir. Kurikulum Berbasis Teknologi Informasi dan Komunikasi.Alfabeta, Bandung, 2008.

[19] Praharsi, Y. Manajemen Pengetahuan dan Implementasinya dalam Organisasi dan Perorangan. Jurnal Manajemen Maranatha, Vol. 16, No. 1 November 2016. Program Studi Manajemen Bisnis. Politeknik Perkapalan Negeri Surabaya, Surabaya, 2016 